\title{
New cuts of bullfrog carcass and its application in asian gastronomy
}

\author{
Novos cortes de carcaça de rã-touro e sua aplicação na gastronomia asiática \\ Nuevos cortes de carcasa de rana toro y su aplicación en gastronomía asiática
}

Received: 02/06/2021 | Reviewed: 02/12/2021 |Accept: 02/16/2021 | Published: 02/24/2021

\author{
Laura Kiyoko Ide \\ ORCID: https://orcid.org/0000-0002-9962-8679 \\ Federal University of Rio de Janeiro, Brazil \\ E-mail: laura.kiyoko@gmail.com \\ José Teixeira de Seixas Filho \\ ORCID: https://orcid.org/00000002 50211290 \\ Fishing Institute Foundation of the State of Rio de Janeiro, Brazil \\ E-mail: jseixas4@gmail.com \\ Sílvia Conceição Reis Pereira Mello \\ ORCID: https://orcid.org/0000-0002-5537-3563 \\ Agricultural Research Company of the State of Rio de Janeiro, Brazil \\ E-mail: silviaqua@uol.com.br \\ Joyce Tarsia Garcia Cafiero \\ ORCID: https://orcid.org/0000-0001-8430-6952 \\ Federal University of Rio de Janeiro, Brazil \\ E-mail: joycecafiero.ufrj@gmail.com
}

\begin{abstract}
The consumption of bullfrog meat has been increasing in Brazil due to its nutritional quality and pleasant texture. The present study aimed to increase the percentage of use of the carcass marketed in the retail market, adding value, with the creation of new cuts in regions previously neglected and discarded, due to the small amount of muscle tissue. A new mapping was created aiming at its full use, in addition to the flank and thigh, innovative regions such as the front legs, hind paw muscles, located just after the thighs, and the last portion of the hind paw. On the back, the cuts called. Back bone and rib were, respectively, the central and peripheral bone parts of the carcass, used in broths and soups, as a technique to add value to these less used cuts in cooking. More elaborate meals were prepared with the thighs. For the valorization of the less noble parts, softening processes were used, by fast or slow cooking, these muscles being added to salads and fillings, respectively. The new cuts were used in the culinary techniques of Asian Gastronomy, being approved through sensory analysis carried out with Maifun salad, with a new version of the Tom Kha Gai soup, one with only bullfrog meat and the other with meat meal. and carcass bones (AABC); and introducing roasted Paris mushrooms in the fillings, providing a better use of the carcass, with a more digestive and hypocaloric menu with health promotion, when compared to traditional cuisine.
\end{abstract}

Keywords: Bullfrog meat; Gastronomy; Asian cuisine; Good manufacturing practices; New carcass cuts.

\section{Resumo}

O consumo da carne de rã-touro vem aumentando no Brasil devido a sua qualidade nutricional e textura agradável. O presente estudo teve por objetivo ampliar o percentual de utilização da carcaça comercializada no mercado varejista, agregando valor, com a criação de novos cortes em regiões antes negligenciadas e descartadas, devido a pouca quantidade de tecido muscular. Foi criado novo mapeamento visando ao seu aproveitamento total, além da fraldinha e coxa, regiões inovadoras como a Palheta (patas dianteiras), músculos da pata traseira, localizados logo após as coxas, e a última porção da pata traseira. No dorso, os cortes denominados de. Suam e Costelinha foi, respectivamente, a parte óssea central e a periférica da carcaça, utilizadas em caldos e sopas, como técnica para agregar valor a esses cortes menos utilizados na culinária. Com as coxas foram preparadas refeições mais elaboradas. Para a valorização das partes menos nobres, utilizou-se processos de amaciamento, por cozimento rápido ou lento, sendo estes músculos adicionados nas saladas e nos recheios, respectivamente. Os novos cortes foram utilizados nas técnicas culinárias da Gastronomia Asiática, sendo aprovados por meio de análises sensoriais realizadas com salada Maifun, com nova versão da sopa Tom Kha Gai, sendo uma somente com carne de rã-touro e a outra acrescida de farinha de carne e ossos da carcaça (AABC); e introdução nos recheios dos cogumelos Paris assados, proporcionando um melhor aproveitamento da carcaça, com um cardápio mais digestivo e hipocalórico com promoção da saúde, quando comparado com a culinária tradicional.

Palavras-chave: Carne de rã-touro; Gastronomia; Cozinha asiática; Boas práticas de fabricação; Novos cortes da carcaça. 


\section{Resumen}

El consumo de carne de rana toro ha ido en aumento en Brasil debido a su calidad nutricional y textura agradable. El presente estudio tuvo como objetivo incrementar el porcentaje de uso de la canal comercializada en el mercado minorista, agregando valor, con la creación de nuevos cortes en regiones previamente desatendidas y descartadas, debido a la pequeña cantidad de tejido muscular. Se creó un nuevo mapeo para aprovecharlo al máximo, además del pañal y el muslo, regiones innovadoras como la paleta (patas delanteras), los músculos de las patas traseras, ubicados justo después de los muslos, y la última porción de las traseras. pata. En la parte de atrás, los cortes llamaron. Suam y Costelinha fueron, respectivamente, las partes óseas centrales y periféricas de la canal, utilizadas en caldos y sopas, como técnica para agregar valor a estos cortes menos utilizados en la cocción. Se prepararon comidas más elaboradas con los muslos. Para la valorización de las partes menos nobles se utilizaron procesos de ablandamiento, por cocción rápida o lenta, añadiéndose estos músculos a ensaladas y rellenos, respectivamente. Los nuevos cortes se utilizaron en las técnicas culinarias de la Gastronomía Asiática, siendo aprobados mediante análisis sensorial realizado con ensalada Maifun, con una nueva versión de la sopa Tom Kha Gai, una con solo carne de rana toro y la otra con harina de carne. Y huesos de canal. (AABC); e introducir setas de París asadas en los rellenos, proporcionando un mejor aprovechamiento de la canal, con un menú más digestivo e hipocalórico con promoción de la salud, en comparación con la cocina tradicional.

Palabras clave: Carne de rana toro; Gastronomía; Cocina asiática; Buenas prácticas de fabricación; Nuevos cortes de canal.

\section{Introduction}

Gastronomy is an office based on the knowledges of tradition and culture, but today it is allowed to create creations, integrated with other arts and sciences. Asian cuisine, especially Japanese cuisine, can be a reference for this trend, because it adds to the wisdom of secular traditions the aesthetic action that is in tune with nature, now a valuable parameter in any artistic manifestation (Takahashi, 2012).

Based on the meats used in Asian cuisine and the risks that they can cause to the health of the individual, it is of great value to analyze the frog meat as an alternative to these menus, once the literature considers it of excellent quality for health, especially those people who have some type of eating disorder.

Frog meat is a white meat that holds resemblance to the rabbit meat and chicken, having its flavor classified as an intermediate between fish and chicken meats and has been cited as a food of great sensory characteristics, high in protein, high minerals and vitamins, and because it presents low values of lipids and cholesterol being, therefore, a meat of low calorific value (Noll e Lindau, 1987; Pelúzio et al., 1995; Ramos 2004; Marengoni \& Santos, 2002).

Therefore, the present work aimed to present new cuts of the frog carcass, aiming at a change of presentation to expand their tasting by Asian cuisine, mainly by people with food intolerance, as well as offer a healthy diet with low cholesterol.

The Chinese meal is guided by several principles. The main one is the Taoist of yin and yang, the two complementary opposites, and the important thing is to seek balance between flavor, temperature, taste, color, texture and consistency of food. One dish should be sweet (yin) and the other salty (yang); One cold (yin) and the other hot (yang); One soft (yin) and one crunchy (yang). The final picture is a banquet that stirs all the senses. A good Chinese dish obeys four "commandments": it has color, perfume, palate and careful presentation (Jesus, 2013).

Dantas (2017) commented that it is not new to use very exotic delicacies, such as shark fins, dog meat, snakes, scorpions and locusts. Such habits, quite exotic to Western standards, have been assimilated by the Chinese because of the periods of poverty, war, and food shortages they have gone through in history.

Kevin (1993) Although they have a common base, it is possible to separate the Chinese gastronomy in four great regions: the one of the North or of Beijing, developed a more exquisite gastronomy, like "Duck of the Pequin", where the crunchy texture of the Skin contrasts with the softness of the flesh, being a perfect menu representing Yang and Yin. In the 
southern regions of the country, sweet represents yin, with the vast production of sugarcane, this is a common seasoning (Carneiro, 2005).

In addition to the concept of yin and yang, there is the concept of the five elements. The Chinese believe they are surrounded by five energy fields: fire, wood, earth, metal and water. In cooking, these elements are represented by the five flavors: (a) bitter - Fire; (B) Sour - Wood; (C) spicy - Metal; (D) sweet - Earth; (E) salty - water. Chinese medicine says that in order to properly treat a patient, you must know the condition of the five elements in that person's body. Deficiency or excess of one of the elements can lead to illness. If an individual suddenly develops a craving for sour foods, this can indicate problems in the liver. Obviously, the diagnosis is much more complex and profound than this (Fahrnow, 2000).

The frog meat is recommended by doctors and nutritionists, because its fat rate is $3 \%$, being the only meat produced in captivity that has the 10 basic amino acids for the human and with easy digestion, being formed by molecules of chains And is indicated especially for the feeding of children who have animal feeding rejection (Lima \& Agostinho, 1988).

The study of the characteristics of the carcass is important when the objective is the evaluation of the quality of the final product of a system (Costa et al., 2002; Restle \& Vaz, 2003; Pacheco et al., 2005, Mello, 2009). Carcass yield and commercial cuts and carcass weight are measures of interest to the slaughterhouses in assessing the value of the product and in operating costs.

The thighs of the animal are more appreciated and the back, usually discarded, becomes a by-product. To take advantage of the interest and the raw material, Embrapa Agroindústria de Alimentos (RJ) has developed products such as pâté, sausages and canned fried meat. The demand for frog meat is higher than the supply in Brazil (Bastos, 2015).

In Brazil frog famers offer the whole carcass to the domestic market as a way to increase their income. The front or "back", composed of the chest and arms is usually scorned by consumers because of the large number of small bones (low meat yield). In order to add value to the segment, several alternatives are being studied to better exploit the meat of this part of the frogs' body, particularly using the mechanical boning machine (Conceição, 2000; Mello et al., 2006; Nóbrega et al., 2007).

The importance of sensory properties in food acceptance has become recognized and a more elaborate methodology for measuring food acceptance and identification of preferences has been developed (Stone \& Sidel, 1993).

In affective tests, subjective attitudes such as acceptance or preference of a product are measured, individually or in relation to others. Judges are usually current or potential consumers of the product (Chaves, 1980; Chaves \& Sproesser, 1999).

In acceptance tests using a hedonic scale, the tester expresses their acceptance for the product, following a previously established scale that varies gradually, based on attributes such as "likes" or "disgust". In verbal-type scales, the choice of words, which identify the intervals in the scale, should give an idea of the successive order of the intervals, as well as facilitate the decision of the taster in his answers (Chaves, 1998).

\section{Methodology}

The present work is classified as a laboratory research, of a qualitative and quantitative nature, as recommended by Pereira et al. (2018), based on the findings of Seixas Filho et al. (2017), Ide (2017) and under standardization by AOAC (2005), ratified by statistical analysis, according to Fonseca (2002) and Pereira et al. (2018).

This work was submitted to the Ethics and Research Committee of the University Center Augusto Motta, constituted under resolution 196/96 of the National Health Council and duly registered in the National Committee of Ethics in Research (CONEP), through the Brazil Platform.

The experiments were carried out at the Gastronomy Laboratory of the University Center Augusto Motta (UNISUAM). 
Frog carcasses were used for the development of slaughterhouse experiments with federal inspection (Figure 1A), where the animals were slaughtered, packed and transported in accordance with current legislation, then thawed (Figure 1B) and deboned according to the purpose of each experiment.

The noble parts and shavings, as well as those closely adhered to the skeletal bone, were added to Asian cuisine (Figures $1 \mathrm{C}$ and $\mathrm{F}$ ).

In the use of the noble part of the carcass, the thigh boning technique was used, separating the bones and cartilage from the musculature (Figure 1D). The hind and front paws were also boned and used as prime beef in Asian cuisine (Figure 1E). The chips served to prepare the broths and thickenings, as a complement to Asian recipes.

After the thawing of the frog carcass, the cuts were started, according to the techniques already reported in the literature (Fragoso, 2012) as the thighs (Figure 1D) and the skirt, then the cuts were made with the new proposals.

A test of acceptance of the frying-goat salad of bull frog meat, of the Mushroom stuffed with bull-fry meat trimmings (skirt, reed and post-thigh) and Tom Kha Gai (soup) the base of bullfrog meat, according to the method of Stone \& Sidel (1992) adapted by Mello (2009), aiming to evaluate the degree of acceptance of the use of different cuts of frog meat in Asian cuisine, aiming at a better utilization of the carcass of the animal.

For the evaluation of the degree of preference between a conventional Asian meal item and a frog meat item with the different cuts, the matched preference test was carried out between the Tom Kha Gai soup, the bullfrog meat base And one with bullfrog meat plus Low-Cost Alternative Food (AABC). The two samples were served coded with three-digit random numbers in two presentation combinations along with shelled bread and rinsed drinking water Of the mouth after each tasting, according to the method described by Chaves and Sproesser (1999). 
Figure 1: Stages of threshing of bullfrog thighs for use in Asian cuisine: receiving carcasses of frogs slaughtered under sanitary legislation (A); Sample of the product and packaging to be boned (B); Beginning of separation of bone musculature (C); Thigh boning (D); Boning of hind paw muscles (E), bone trimmings and broth cartilage (JUS) (F); Bones for making flour ( $\mathrm{G}$ and $\mathrm{H})$.
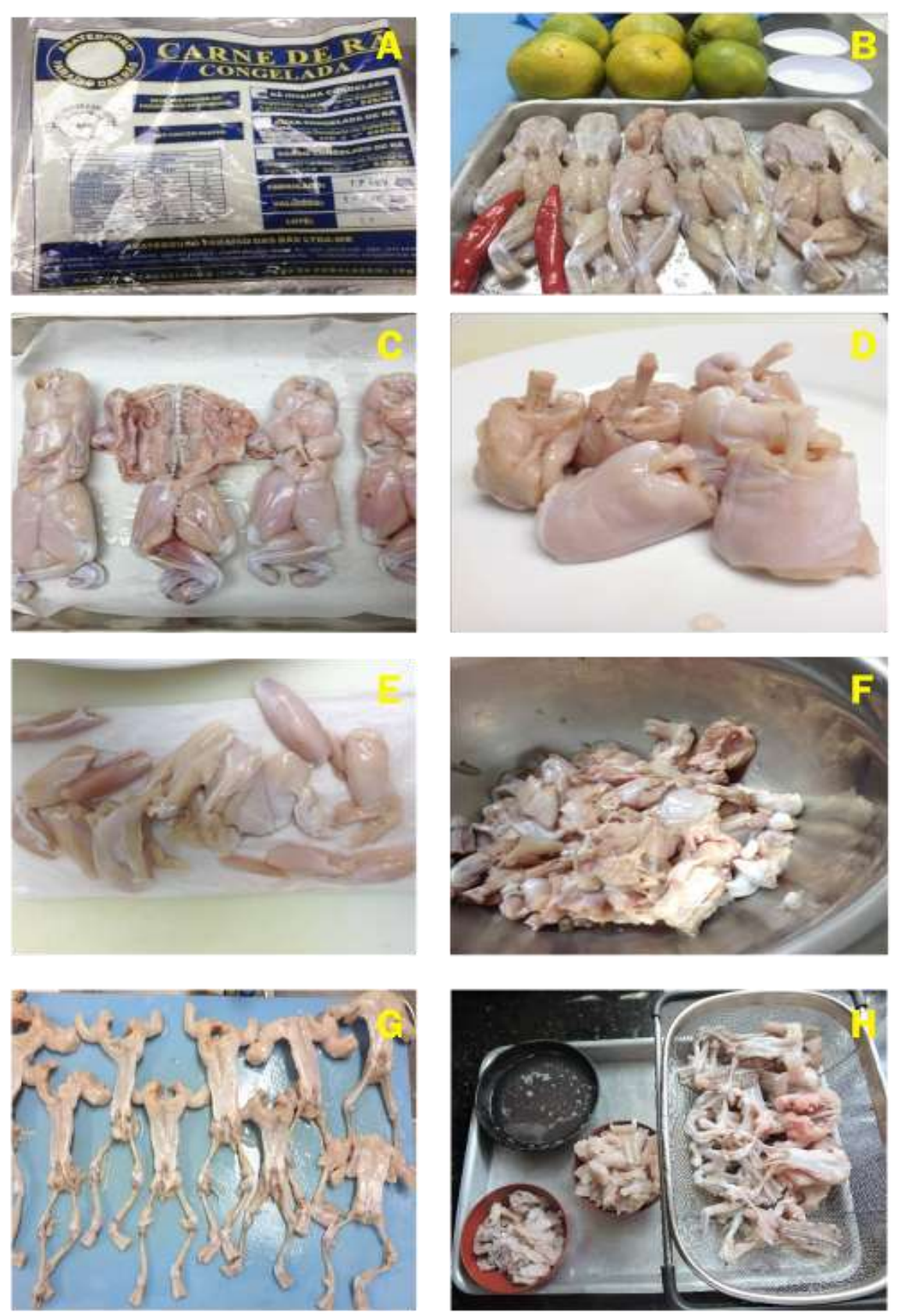

Source: Authors.

\section{Results and Discussion}

In relation to the proposal to extend the applicability of the bullfrog carcass, based on gastronomic cutting and cooking techniques, advances were made in the expansion of the use of the non-noble parts, increasing their palatability through asian cuisine menus. 
Figure 2: Mapping of the different regions of the bullfrog carcass, with the classic types (A) flank and (B) Thigh and for total use, the following meats were included in the menus of Asian cuisine: (C) Legs Front, (D) Against Thigh and Post-thigh (E). In addition to the use of the carcass, a low-cost, calcium-rich alternative food was prepared in the form of farinaceous, composed of bone and musculature adhered to the carcass, mainly (F), Back bone and (G) Rib. The new proposed thigh cut, with the use of the first portion of the hind paw $(\mathrm{H})$.

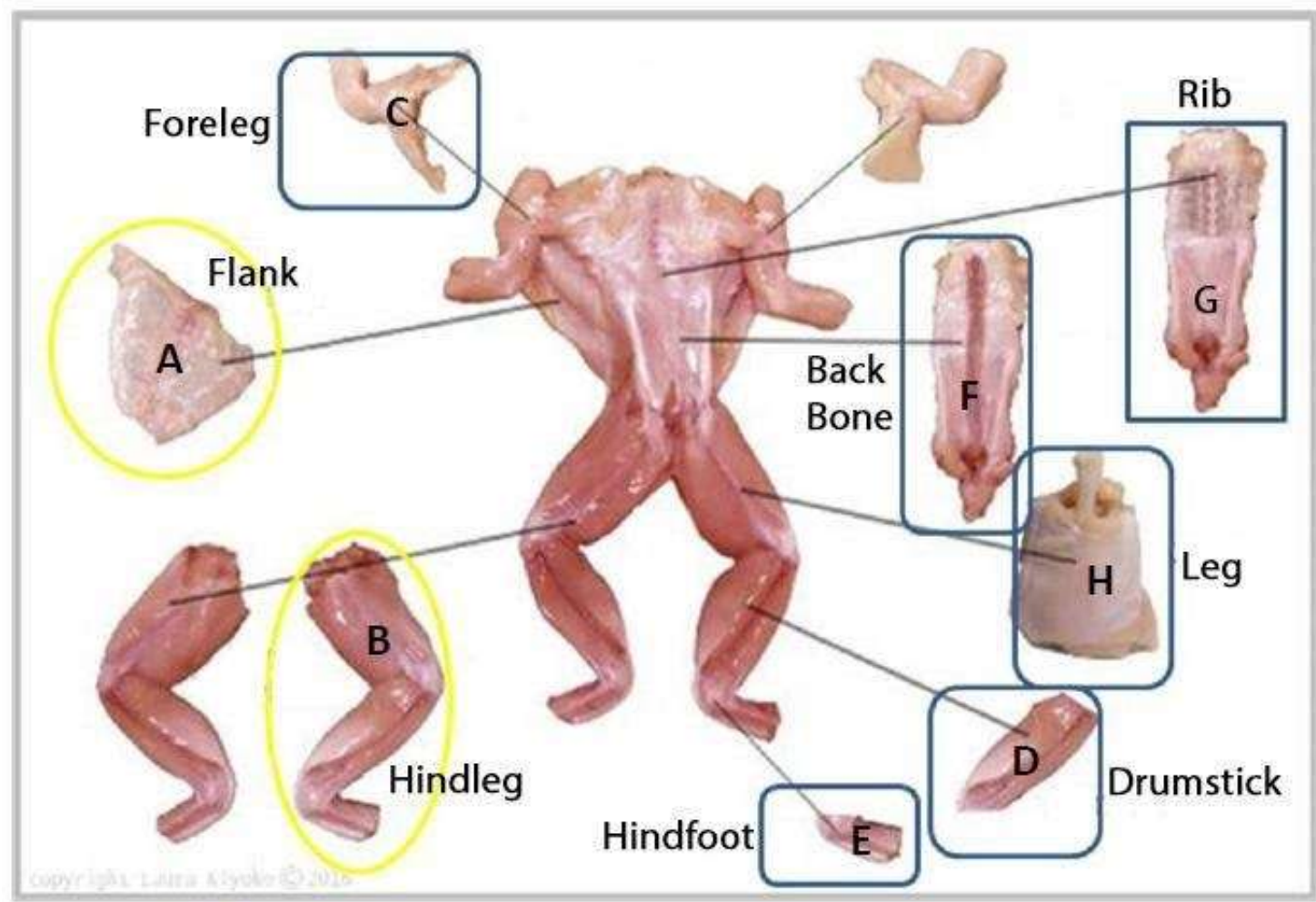

Traditional Cutting Fragoso (2012)
Source: The Authors

Source: Authors.

The results confirm those reported by Bastos (2015) when, in addition to enhancing their nutritional benefits, he emphasized the soft taste of bullfrog meat, even comparing it as an intermediary between chicken meat and fish.

On the other hand, the results obtained from the introduction of the skewer in asian cuisine were different from that attributed by Bastos (2015) when considering the back of the bullfrog carcass as a by-product, reporting its use only after processing, Such as pâtés, sausages and preserves, discarding their use in the natural way.

The Hindfoot is the final region of the hind paws that would attach to the dyads joined by the interdigital membrane, which are removed during slaughter. It is an extremely rigid region, with musculature firmly adhered to the skeleton and was used as a trimmings, along with the skirt and the reed, being part of the soup and the stuffing for the mushroom,

The valorization of the use of the frog meat trimmings (skirt, reed and hindfoot) enabled the proposal of Fragoso et al. (2012), when they concluded that the manipulation of the food of the less noble parts of the bullfrog carcass would reduce the price, creating a more accessible market, corroborating Lima and Agostinho (1998), who showed concern that only half of the carcass is being sold Like noble meat, remaining the other products, as the whole or bony back and the back in pieces, little explored.

The results of calculations of nutritional information (TACO, 2011) of the asian menus elaborated with the inclusion 
of the less noble regions of the bullfrog carcass (Table 1), showed in protein terms, a similar percentage, almost $1 / 3$ of the food, For Tom Khai Gai soup, promoting such a nutritious food when compared to the original recipe that has chicken breast meat as the source of protein (Thai, 2008). Similar results were obtained when comparing the Maifum Salad with bullfrog and chicken trimmings (Santana \& Belo, 2004).

Table 1: Results of Nutritional Information of the Asian cuisine menus made with the introduction of shavings (little diaper, pallet and post-thigh) of bullfrog meat.

\begin{tabular}{|c|c|c|c|c|c|c|c|c|c|c|c|c|c|c|}
\hline \multirow[t]{2}{*}{ Menu } & \multicolumn{2}{|c|}{ Carbohydrate } & \multicolumn{2}{|c|}{ Protein } & \multicolumn{2}{|c|}{$\begin{array}{l}\text { Total } \\
\text { Fat }\end{array}$} & \multicolumn{2}{|c|}{$\begin{array}{c}\text { Fats } \\
\text { Saturated }\end{array}$} & \multicolumn{2}{|c|}{$\begin{array}{c}\text { Trans } \\
\text { Fat }\end{array}$} & \multicolumn{2}{|c|}{ Fiber } & \multicolumn{2}{|c|}{ Sodium } \\
\hline & $\mathbf{g}$ & $\%$ & $\mathbf{g}$ & $\%$ & g & $\%$ & g & $\%$ & g & $\%$ & g & $\%$ & $\mathrm{mg}$ & $\%$ \\
\hline $\begin{array}{l}\text { Tom khai gai }{ }^{1 *} \\
(392 \mathrm{kcal}=19,59 \\
\mathrm{KJ})\end{array}$ & 18,0 & 19,2 & 20,5 & 27,4 & 25,6 & 46,5 & 1,0 & 4,6 & $\mathbf{0}$ & $\mathbf{0}$ & 9,9 & 39,6 & 318,2 & 13,2 \\
\hline $\begin{array}{l}\text { Maifum 'Salad }{ }^{2} * * \\
(176 \mathrm{kcal}=9 \mathrm{KJ})\end{array}$ & 2,5 & 0,8 & 1,9 & 2,5 & 18,0 & 33,0 & 4,2 & 19,0 & $\mathbf{0}$ & $\mathbf{0}$ & 0,5 & 2,0 & 31,0 & 1,3 \\
\hline $\begin{array}{c}\text { Mushroom } \\
\text { Stuffed }^{\mathbf{3}} * * * \\
\left(272 \mathrm{kcal}^{2} 14 \mathrm{KJ}\right)\end{array}$ & 0,8 & 0,3 & 9,0 & 12,0 & 7,5 & 14,0 & 2,1 & 10,0 & & 0 & 0,6 & 2,4 & 63,0 & 2,6 \\
\hline
\end{tabular}

${ }^{1}$ Nutritional information: portion 50g (4 tablespoons) Amount per serving (\% DV). Daily reference values based on a 2000 kcal or 8400 KJ diet. Your daily values may be higher or lower depending on your energy needs. DOES NOT CONTAIN GLUTEN

* Southeast Asian soup consisting of shavings (region of the skirt, the reed and the post-against thigh of the bullfrog) and the Alternative Food of Low Cost $(\mathrm{ABBC})$ in the form of meat meal and frog bones.

${ }^{2}$ Nutrition Facts: 50g serving (4 tablespoons). Amount per serving (\% DV). Daily reference values based on a $2000 \mathrm{kcal}$ or $8400 \mathrm{KJ}$ diet. Your daily values may be higher or lower depending on your energy needs. DOES NOT CONTAIN GLUTEN

** Salad composed of the region of the bull frog carcass denominated little diaper with rice noodles (bifun)

${ }^{3}$ Nutritional information: portion $80 \mathrm{~g}$ ( 1 unit) Amount per serving (\% DV). \% Daily reference values based on a $2000 \mathrm{kcal}$ or $8400 \mathrm{KJ}$ diet. Your daily values may be higher or lower depending on your energy needs. DOES NOT CONTAIN GLUTEN

*** Shitaki mushroom stuffed with a mix of parsnip (skirt, reed and post-thigh) of frog-bull Source: Taco (2011)

The nutritional results are also in agreement with several researches already carried out (Conceição, 2000; Mello et al., 2006; Nóbrega et al., 2007) that recognized in the bull frog meat an interesting nutritional profile, presenting characteristics that make it indicated For low calorie diets.

In relation to the sensory evaluation of the typical Asian dishes and sauces (Table 2), it is possible to evaluate the acceptance of the introduction and the use of different cuts of frog meat, which showed that the worst evaluation for the Mushroom Paris Stuffed. This result may have been due to the fact that the evaluators did not have a habit of consuming the mushroom in natura but rather preserved in the so-called champignon form, since the consumption of the stuffing (bull fodder meat) was observed and left, As it were, the vegetative body of the mushroom.

In relation to the salad Maifum with little diaper, this one obtained intermediate position. However, its highest score was precisely for the texture, with $5.90 \pm 0.16$, which meant the approval by the evaluators for the introduction of a part of the bull frog carcass formerly considered non-noble, even being called as a by-product (Bastos, 2015). This fact was also confirmed by the attribution of the consumption note $(4.14 \pm 0.17)$ of this menu, which did not present a significant difference $(\mathrm{P}<0.05)$ among the menus of better acceptance. 
Table 2: Results of the sensory analysis of Asian cuisine menus with the introduction of bullfrog meat.

\begin{tabular}{cccccc}
\hline Treatment & Appearance & Sabor & Texture & $\begin{array}{c}\text { Printing } \\
\text { Global }\end{array}$ & Consumption \\
\hline T1 & $5,74 \pm 0,18 \mathrm{a} *$ & $5,84 \pm 0,18 \mathrm{~b}$ & $5,90 \pm 0,16 \mathrm{bc}$ & $5,88 \pm 0,17 \mathrm{~b}$ & $4,14 \pm 0,17 \mathrm{a}$ \\
T2 & $5.08 \pm 0,22 \mathrm{~b}$ & $4,88 \pm 0,24 \mathrm{c}$ & $5,32 \pm 0,23 \mathrm{c}$ & $5,24 \pm 0,22 \mathrm{c}$ & $3,38 \pm 0,21 \mathrm{~b}$ \\
T3 & $6,08 \pm 0,15 \mathrm{a}$ & $6,30 \pm 0,13 \mathrm{ab}$ & $6,30 \pm 0,15 \mathrm{ab}$ & $6,42 \pm 0,12 \mathrm{ab}$ & $4,50 \pm 0,13 \mathrm{a}$ \\
$\mathrm{T} 4$ & $6,30 \pm 0,14 \mathrm{a}$ & $6,58 \pm 0,12 \mathrm{a}$ & $6,53 \pm 0,13 \mathrm{a}$ & $6,64 \pm 0,09 \mathrm{a}$ & $4,56 \pm 0,14 \mathrm{a}$ \\
\hline Value -P & $<0,0001$ & $<0,0001$ & $<0,0001$ & $<0,0001$ & $<0,0001$ \\
\hline
\end{tabular}

Treatments: T1 - Maifum fry skirt salads; T2 - Mushroom Paris stuffed with fodder (skirt, reed and post-thigh) frog; T3 - Tom Kha Gai's frog with AABC (meat-and-bone meal); T4 - Tom Kha Gai of frog,

* The means with different letters in the same column with different letters differ by the Tukey test at 5\% probability.

* Mean \pm standard deviation.

Source: The Authors.

As for the Tom Kha Gai soups analyzed in the Pareto Test and the results analyzed by the Roessler et al. (1978), it can be verified that only 31 of the 50 evaluators preferred the soup without the addition of meat-and-bone meal. However, this result showed no significant difference $(\mathrm{P}<0.05)$ between the two compositions, that is, the soup that received only the trimmings (skirt, reed and hindfoot) of bullfrog meat obtained the same preference The meat and bone meal, known as AABC (Low Cost Alternative Food), which enabled the introduction in this menu of about $1 / 4$ in its composition of minerals, including Calcium, which (Noll et al., 2000), it is possible to infer that this menu has a promise of being an excellent functional food for people with deficiency in this mineral.

Based on the nutritional characteristics of frog meat, its inclusion in the soup, due to its high protein digestibility, allows to consider it a representative of yang energy, creating an active, more dynamic, more extroverted attitude, agreeing with Varatojo (2011).

The Maifum salad that made possible the valorization of the carapace trimmings of the bullfrog has the sweet taste of the yin of the sugar and the culinary liqueur sake and the salty yang of the Shoyu sauce; The lettuce is representing the concept of cold, that is, the yin and the fried bifur pasta, the hot part of the food, giving the crunchiness and the yang state of the menu. On the other hand, the softness is observed by the presence of the mushroom and the frog meat, segmented in small tender slices, characterized the yang state of the food. The whole of the ingredients of this salad emphasized all the senses, according to a good Chinese dish, by having the four "commandments": color, perfume, palate and careful presentation corroborating Jesus (2013) and Varatojo (2011).

\section{Conclusion}

It was possible to enlarge the different muscle regions of the bullfrog carcass by inserting new cuts, starting to use the parts previously discarded for consumption, remodeling the classification cuts in the use of the carcass that will be marketed for different gastronomic purposes, such as flank and Drumstick in salads; Foreleg, Hindleg, Back Bone and Rib for broths and fillings, making asian cuisine more economical and healthy.

\section{References}

AOAC. (2005). Official methods of analysis of the Association Analytical Chemists. (18a ed.), Maryland. 
Bastos, A (2015). Pesquisa investe em rã desenvolve produtos: manual e cria rede de cooperação. In: Embrapa Agroindústria de Alimentos agroindústria-de-alimentos. http://www.embrapa.br/busca-de-notícias.

Carneiro, H. S. (2005). Comida e Sociedade: Significados Sociais na História da Alimentação. In: História: questões \& debates, Curitiba: Editora UFP (42), 71-80.

Chaves, J. B. P (1980). Avaliação sensorial de alimentos: método das análises. UFV, 69 p.

Chaves, J. B. P. (1998). Análise sensorial: histórico e desenvolvimento. Universidade Federal de Viçosa: Impressa Universitária. $31 \mathrm{p}$.

Chaves, J. B. P., \& Sproesser, R. L. (1999) Prática de laboratório de análise sensorial de alimentos e bebidas. Universidade Federal de Viçosa: Impressa Universitária, 91 p.

Conceição, C. (2000) Utilização de carne de dorso de rã (Rana catesbeiana, Shaw 1802) no desenvolvimento de um produto alimentício. 2000. 102f. [Dissertação Mestrado] Universidade Federal Rural do Rio de Janeiro, Rio de Janeiro.

Costa, E. C, Restle, J., Vaz, F. N., Alves Filho, D. C., Bernardes, R. A. L. C., \& Kuss, F. (2002). Características da carcaça de novilhos Red Angus superprecoces abatidos com diferentes pesos. Revista Brasileira de Zootecnia, 31 (1), $119-128$.

Dantas, T. (1994). Culinária Chinesa. In: Della Modesta, R. C. Manual de análises sensorial de alimentos e bebidas: prática. Rio de Janeiro: EMBRAPA. CTAA, (3),. 46 p.

Fahrnow, J. H. (2000). Feng Shui and the 5-Element Kitchen (Vitality Cooking Series). San Francisco: Silverback Books. 166 p.

Fonseca, J. J. S. (2002). Metodologia da pesquisa científica. Fortaleza. Universidade Federal do Ceará. 127p.

Fragoso, S. P. (2012). Avaliação de características físico-químicas da carne de rã-touro (Lithobates catesbeianus) liofilizada de pigmentação normal e albina. 2012. 89 f. [Dissertação Mestrado] Universidade Federal da Paraíba, Bananeiras.

Ide, L. K. (2017). Ampliação da utilização da carcaça de rã-touro com introdução na culinária asiática. 2017. 104f. [Dissertação Mestrado] Centro Universitário Augusto Motta, Rio de Janeiro.

Jesus, S. (2013). O mundo da cozinha chinesa. Revista Macau, Singapura. Recuperado de: <http://www.revistamacau.com>. Acessado em: 9 jan. 2021.

Kevin. S. (1993). O mais belo livro da cozinha da china. Verbo (Ed.), Maia, 256 p.

Koneman, E. W., Allen, S. D., Janda, W. M., Schreckenberger, P. C., \& Winn JR., W. C. W. (2001). Diagnóstico microbiológico. (5a ed.), Medsi. 1465 p.

Lima, S. L., \& Agostinho, C. A. (1988) Ganho de peso e conversão Alimentar da rã-touro, Rana Catesbeiana, com ração (Ensaios preliminares). In: Encontro Nacional Ranicultura, 7, 1988, Rio de Janeiro. Anais... Rio de Janeiro: Associação dos Ranicultores do Estado do Rio de Janeiro.

Lima, S. L., Teixeira, R. D., \& Costa, M. (2006). Desenvolvimento de pratos prontos a base de carne de rã (in sous-vide). Workshop GI-Pescado: “Inovações Tecnológicas e Valor Agregado na Tecnologia do Pescado: Pesquisas Brasileiras".

Mello, S. C. R. P. (2009). A carne de rã: processamento e industrializado. Publit. 134 p.

Mello, S. C. R. P., Pessanha, L. S., Mano, S., Franco, R. M., Pardi, H. S., \& Santos, I. F. (2006). Avaliação Bacteriológica e Físico-Química da Polpa de Dorso de Rã Obtida por Separação Mecânica. Brazillian Journal Food Technology, 9 (1). $39-48$.

Moura, O. M. (2003). A rã e o uso potencial de seus derivados na indústria de alimentos. Revista Panorama da Aquicultura, 13 (80). 27-31.

Nóbrega, I. C. C., Ataíde, C. S., Moura, O. M., Livera, A. V., \& Menezes, P. H.(2007). Volatile constituents of cooked bullfrog (Rana catesbeiana) legs. Food Chemistry, 102, 86-191. 
Noll, I. B., \& Lindau, C. F. (1987). Aspectos da composição em nutrientes da carne de rã-touro gigante (Rana catesbeiana). Cadernos de Farmácia, Porto Alegre, 3 (1/2), 29-36.

Pacheco, P. S., Silva, J. H. S., Restle, J., Arboitte, M. Z., BrondanI, I. L., Alves Filho, D. C., \& Freitas, A. K. (2005) Características quantitativas da carcaça de novilhos jovens e superjovens de diferentes grupos genéticos. Revista Brasileira de Zootecnia 34 (5), p. 1666-1677.

Pereira, A. S., Shitsuka, D. M., Parreira, F. J., \& Shitsuka, R. (2018). Metodologia da pesquisa científica. UFSM. https://repositorio.ufsm.br/bitstream /handle/1/15824/Lic_Computacao_Metodologia-Pesquisa-Cientifica.pdf?sequence=1.

Restle, J., \& Vaz, F. N. (2003). Eficiência e qualidade na produção de carne bovina. In: Reunião Anual Da Sociedade Brasileira De Zootecnia, 40, Santa Maria. Anais... Santa Maria: SBZ, 34 p. CD-ROM. Palestra 11.

Roesller, E. B., Pangborn, R. M., Sidel, J. L., \& Stone, H. (1978). Expanded statistical tables for estimating significance in paired-preferences, duo-trio and triangular test. Journal of Food Science, 43 (3), 940-943.

Santana, C. P. B, \& Belo, J. M. (2004) Cozinha Tailandesa. Vernáculo Ltda.: 96 p.

Seixas Filho, J. T., Pereira, M. M., \& Mello, S. C. R. P. (2017). Manual de Ranicultura para o Produtor. Rio de Janeiro: Fundação Instituto de Pesca do Estado do Rio de Janeiro (Fiperj). 155 p.

Stone, H., \& Sidel, J. L. (1993). Sensory evaluation practices. Academic Press, INC, 377 p.

Taco. (2011). Tabela Brasileira de Composição de Alimentos. Núcleo de Estudos e Pesquisas em Alimentação (NEPA). Campinas: Universidade Estadual de Campinas. 164 p.

Thai, S. (2008). A Cozinha Tailandesa. Larousse Editora, 128 p.

Varatojo, F. (2011) Yin e Yang: Publicação de janeiro de. Instituto Macrobiótico de Portugal. <http://www.institutomac robiotic $0 . \mathrm{com} / \mathrm{pt}>$. 